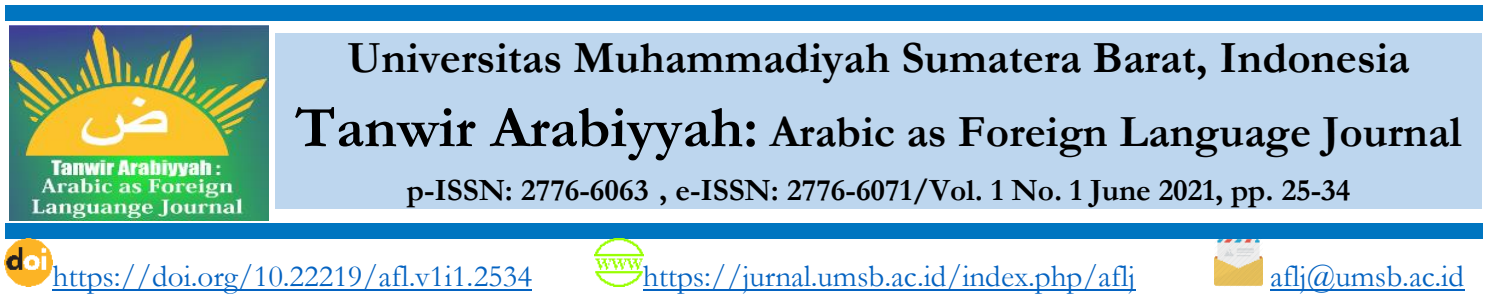

\title{
Analysis of Arabic Textbook "Takallam Bil 'Arabiyyah Volume 6" Based on Mickey's Theory
}

\author{
Apri Wardana Ritonga \\ UIN Maulana Malik Ibrahim Malang, Indonesia \\ wardanaapri90@gmail.com
}

\begin{tabular}{|c|c|}
\hline ARTICLE INFO & ABSTRACT \\
\hline $\begin{array}{l}\text { Article History: } \\
\text { Received: } 25 \text { February } 2021 \\
\text { Revised: } 04 \text { March } 2021 \\
\text { Accepted: } 01 \text { May } 2021 \\
\text { Published: 01 June } 2021\end{array}$ & $\begin{array}{l}\text { Textbooks have an important role in achieving learning success. learning } \\
\text { will run effectively if the teaching materials used are in accordance with } \\
\text { the learning objectives. it is necessary to do an in-depth study of the } \\
\text { textbooks used in schools. This study aims to analyze the textbook } \\
\text { "Takallam Bil'Arabiyyah Volume 6" which is used in Arabic learning based } \\
\text { on Mackey's theory. This study uses the literature study method. Sources } \\
\text { of data were taken from articles, books, research reports, and textbooks } \\
\text { "Takallam Bil 'Arabiyyah Volume 6" with data analysis techniques using } \\
\text { descriptive analysis. Finally, the data is presented using the deductive } \\
\text { method, which describes general phenomena to the findings of the } \\
\text { analysis. This research reveals that the textbook "Takallam Bil 'Arabiyyah } \\
\text { Volume 6" was compiled based on the theory of William Francis Mackey. } \\
\text { This can be seen from the presentation of the material which contains the } \\
\text { concepts of selection, gradation, presentation, and repetition. The } \\
\text { development of the textbook "Takallam Bil'Arabiyyab Volume 6" needs to } \\
\text { be done by adding more factual material for student life in the } 21 \text { st- } \\
\text { century era. }\end{array}$ \\
\hline \multirow[t]{3}{*}{ Keyword } & Arabic Learning; Mackey's Teory; Textbook \\
\hline & $\begin{array}{l}\text { Copyright (C) 2021, Apri Wardana } \\
\text { This is an open access article under the CC-BY-SA license }\end{array}$ \\
\hline & \\
\hline \multicolumn{2}{|c|}{ 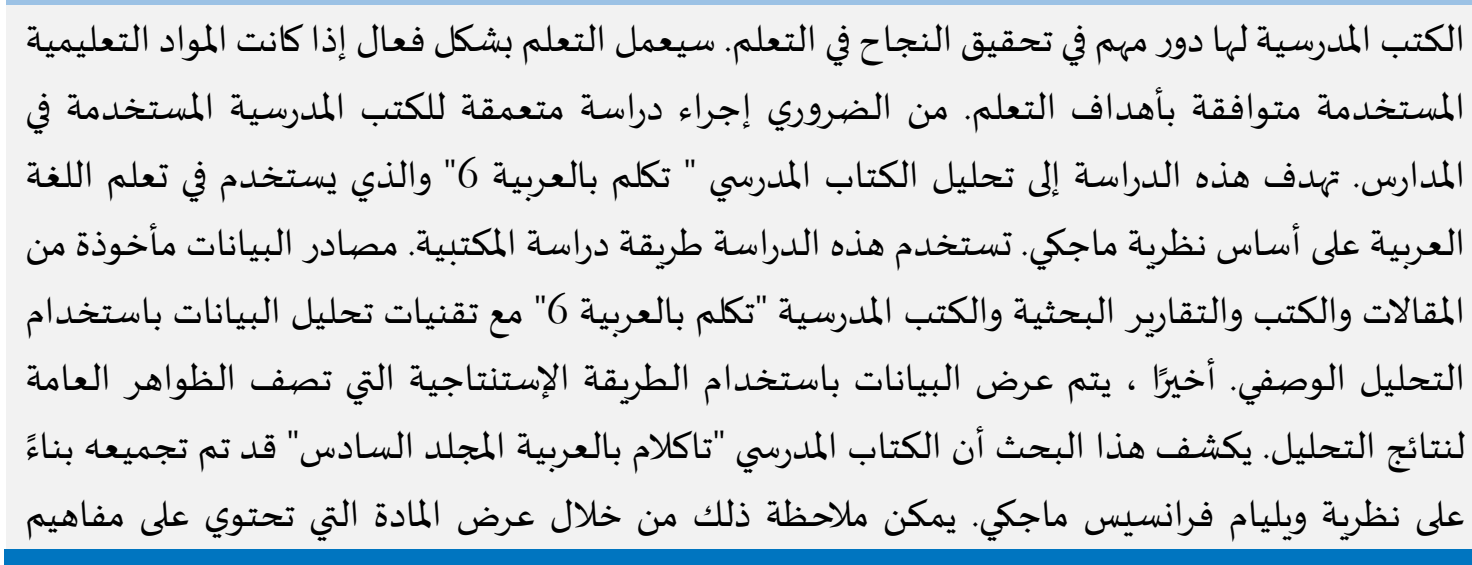 } \\
\hline
\end{tabular}




$$
\begin{aligned}
& \text { الإختيار والتدرج والعرض والتكرار. يجب أن يتم تطوير الكتاب المدرسي " تكلم بالعربية 6" عن طريق إضافة } \\
& \text { المزيد من المواد الواقعية لحياة الطلاب في عصر القرن الحادي والعشرين. } \\
& \text { كلمات أسـاسية تعليم اللغة العربية؛ الكتب المدرسي؛ نظرية ماجكي }
\end{aligned}
$$

\section{INTRODUCTION}

Learning Arabic is one of the main lessons in Islamic schools in Indonesia from the madrasah Ibtidaiyah (MI) to higher education (PT) levels. Until now, Indonesian students consider Arabic as a frightening specter and consider it a difficult subject (Ahmad, 2015; Irfan, 2020; Setyawan \& Ahsan, 2020). Not only students but Arabic teachers also do not fully understand the language lessons they teach, they lack skills in developing proper learning (Imam Makruf, 2020). Fitriani \& Saefuloh (2018) Assess it is necessary to review the content of the material contained in Arabic lessons, the curriculum used, the learning media chosen, and the textbooks used.

Tarigan \& Tarigan (1986) explain some of the definitions of textbooks as follows, (1) textbooks are textbooks aimed at students at a certain level of education, (2) textbooks are always related to certain fields of study, (3) textbooks are standard books, namely books that become references, have quality and usually have a sign of approval from the competent authority, (3) textbooks are usually prepared by experts in their respective fields, (4) textbooks are written for specific instructional purposes, (5) ) ordinary textbooks are also equipped with teaching facilities, (6) textbooks are always written to support a teaching program.

Arabic textbooks used in schools need to be seriously studied. This is done because teaching materials are an important component in the success of learning. if the teaching materials used are in accordance with the criteria of a good textbook, the learning will run effectively. William Francis Mackey explains the four criteria for a good textbook that must be in the textbook used, namely selection, gradation, presentation, and repetition (Sumardi, 1974). Through these four criteria, it makes it easier for teachers to prepare subject matter to realize the desired learning goals (Ninoersy et al., 2019).

Several previous studies revealed the importance of analyzing textbooks used in learning. research conducted by Akbar \& Yusuf (2018) reveals that the strategic position of textbooks in learning Arabic is reflected in its role as a medium in transferring knowledge, ideology, and culture. Therefore, giving attention to the primary principles in writing Arabic textbooks is a necessity. Pahlefi (2020) added that in the process of compiling a textbook and formulating the material in it, it must go through an in-depth study so that the book is a quality handbook. Because quality books will be very influential in supporting the learning process, both students and teachers. Setyawan et al (2018) explain quality textbooks, namely the preparation of material according to the objectives, material content according to the level of proficiency of students, and the length of a language learning program. Ramah \& Rohman (2018)) said that in addition to material aspects that are goaloriented, textbook writing is expected to pay attention to aspects of diversity, so that multicultural values will be embedded in students. Finally, Hadi (2018) emphasized that the aspect of the suitability of the Arabic language book content with the 2013 curriculum content as a formal foundation for the education curriculum in Indonesia must also be considered in compiling textbooks.

Based on the analysis of previous research, it was found the urgency of the analysis of Arabic teaching materials as an inseparable unit in learning activities. the research above 
only analyzes the teaching materials in general to describe the relevance of using the teaching materials in schools. In the preparation of teaching materials, there are many expert theories that can be used as a reference, such as William Francis Mackey who has his own views on how to compile a good textbook, by looking at four elements, namely selection (material selection), gradation (sorting), presentation and repetition. (repetition). Based on this, the author is very interested in analyzing the Arabic textbook "Takallam Bil 'Arabiyyah" by Mamluatul Hasanah for the XII grade high school level and other supporting aspects according to William Francis Mackey's theory which will eventually be linked to Mamluatul Hasanah's thoughts in the preparation text book.

\section{METHOD}

The research method uses the method of library research, which is research that utilizes library materials as a source of data to answer the formulation of research problems. The data collection method is done by collecting various literature in the form of books, scientific articles, historical records, scientific reports that discuss the object of research. The data collected was then read, analyzed, recorded using descriptive analysis methods.

In analyzing the data, the researcher refers to four aspects in the preparation of teaching materials according to Mackey's theory, which includes: selection, gradation, presentation, and repetition. Researchers look at these four aspects whether they are already contained in the textbook "Takallam Bil 'Arabiyyah". The data that has been analyzed is then presented with a deductive method that departs from general theory to lead to research conclusions.

\section{RESULTS \& DISCUSSION}

\section{The Concept of Presentation of Teaching Materials According to Mackey's Theory}

According to William Francis Mackey, good teaching materials used in the learning process are teaching materials that fulfill four main elements, namely selection, gradation, presentation, and repetition. Hadi (2018) explains the four elements as follows:

\section{Selection}

In the preparation of textbooks, the material selection process must be carried out because it is impossible to teach all material that is in one language or any field of science. Not yet found a single correct formulation to teach all aspects of the material in language learning. The method used in learning must also be selected according to the material being taught, the selection of sound, vocabulary, semantics, and grammar. In this case, it is vocabulary learning that should undergo selection, because of the large number of vocabularies, vocabulary that must be known only by students is chosen. The things to pay attention to in selecting vocabulary are language learning objectives, level of proficiency, and length of study time. Things that must be selected in the preparation of teaching materials: a) learning objectives. The first selection process is knowing the learning objectives of each material taught to students. This is done so that in addition to teachers, students also know what skills will be acquired after studying the material. $b$ ) the level of student ability. The selection of the next material is based on the level of ability of the students, in the case that grade I students of Madrasah Ibtidaiyah are equivalent to grade I in Elementary Schools. Where students at this level are at the most basic level (basic). So that the material chosen from the selected themes must also be very basic. Febriani (2020) said that the basic material that is properly taught to elementary school students is the 
sound aspect of the Arabic language. Because this Arabic material continues to the next and higher levels, the selection of Arabic language material must also pay attention to the principle of gradation. c) allocation of study time. The subject matter contained in textbooks must pay attention to the allocation of learning time used in schools, considering that learning time in schools is very limited. As regulated in the regulation of the Minister of National Education (Permendiknas) number 22 of 2006 concerning Standard Content which refers to Government Regulation Number 19 of 2005 concerning National Education Standards, it is stated that the learning load for face-to-face activities per learning hour in each educational unit is determined as follows: SD/MI/SDLB lasts 35 minutes; SMP/MTs/SMPLB lasts 40 minutes; SMA/MA/SMALB/SMK/MAK lasts 45 minutes. d) Use of language. The language used in textbooks must be selected properly. The language used here is Fusha or 'Amiyah. These two types of language must be introduced to students in the content of teaching materials so that students know the difference between Fusha and 'Amiyah languages well.

\section{Gradation}

Gradation is a gradual arrangement of material, starting from easy material then progressing to more difficult material gradually until finally to really difficult material. Because the material cannot be delivered all at once. A textbook that uses the concept of gradation, will make it easier for students to better understand the contents of the book. In this case, Mackey put forward two important conditions so that books can be called fulfilling the concept of gradation, namely: grouping and sorting (gradation). Grouping must be based on the principles of uniformity, contrast, and parallels. While sequencing must be based on the principles of learning psychology, namely from general to specific, from short to long, from simple to complex.

\section{Presentation}

After going through the selection and gradation stages, the next stage is the presentation. Presentation is how material that has been selected and grouped can be conveyed and understood by students. Here are several procedures for presenting a material:

\section{a. Differential}

A procedure that is based on the difference in meaning between one language and another. According to this procedure, to understand a meaning, the language of the students is used, namely by translating or explaining the material using the students' language. Student language can be used to explain the meaning of a word and its usage, grammar rules, differences in sentence patterns, sounds, and so on. The difficulty with this method is that there are many foreign terms and words in textbooks that have not been translated into the language of the students.

b. The ostensive

The procedure is a way of teaching language using body language, namely the movements of the hands, eyes, face, and others. Teach nouns can be done by pointing directly to the objects in question, or by bringing these objects into the classroom. Verbs can be taught by showing the gestures of the hands or other limbs.

c. The pictorial

The procedure is a teaching procedure using pictures. There are three kinds of pictures used in language teaching, namely as follows: a) Thematic images. Thematic images 
are images that are used as illustrations of a theme or text. For example, a picture of a family eating together, or a picture of a natural landscape. b) Mnemonic images. Mnemonic pictures are pictures made to help students remember the meaning of a particular word or sentence. The mnemonic image can be a picture of a situation that is simultaneously presented with sentences about the situation. c) Semantic images. Semantic images are images to teach meaning. Therefore, the picture must be clear and not have a double meaning. Apart from these images, other media that can be used are films, film strips, slides, wall pictures, flashcards, and stick figures. d) Context procedure. Context procedures are teaching procedures that are verbal in nature. Such as the use of definition, enumeration, substitution, metaphor, opposition, and multiple contexts.

4. reps

Mackeyreps group split into four sections that are tailored to the four language skills, namely listening, speaking, reading, and writing. Repetition is a step taken for the material presented to be digested and internalized by language learners into language skills that are ready to use. The sharpening technique (repetition) that is most commonly used is a receptive and productive exercise. Receptive exercises are exercises to improve listening and reading skills. Meanwhile, productive exercises are exercises to improve speaking and writing skills.

\section{Analysis of Textbook "Takallam Bil 'Arabiyyah Volume 6" According to Mackey's Theory}

a. Material selection

As previously explained, Mackey formulated four components that must be included in the material selection points, namely learning objectives, student ability levels, time allocation, and language use. Based on these four points, the researcher saw that the selection of material in the book "Takallam Bil 'Arabiyyah Volume 6" already contains elements of selection as described by Mackey, but it is not complete. In terms of learning objectives, researchers did not see the learning objectives to be achieved in the textbook "Takallam Bil 'Arabiyyah Volume 6". While the formulation of important learning objectives is included in the textbook as knowledge for students in studying the material. In terms of choosing the name of the book, "Takallam Bil 'Arabiyyah Volume 6", the textbook emphasizes the speaking skills of students. Students who are proficient in speaking Arabic are the main objective of the preparation of the textbook. As stated by Setyawan \& Ahsan (2020), one of the goals of learning Arabic is the purpose of communication. Followed by other goals such as cultural goals, interrelation with other nations, community goals, and comparative goals.

Selection of material based on student ability levels, the book "Takallam Bil 'Arabiyyah Volume 6" contains four skills, among others, listening skills, speaking skills, reading skills, and writing skills. The material taught in the book "Takallam Bil 'Arabiyyah Volume 6" is classified into two parts, first, relating to the environment, second, related to activities related to students.

Table 1. Learning materials

\begin{tabular}{ll}
\hline \multicolumn{2}{c}{ المواد } \\
\hline المعوايات \\
\hline
\end{tabular}




\begin{tabular}{ll}
\hline السفرمال في المجتع \\
\hline الساعة
\end{tabular}

Then, when viewed in terms of the level of the teaching material, it can be classified into three levels, namely learning Arabic at the basic level, the intermediate level, and the advanced level. In the preparation of these teaching materials, there is also a length of study time which takes one year to learn Arabic or two semesters (odd and even semesters), and each semester is in accordance with (SK) competency standards, and (KD) basic competencies that have been determined. Finally, the language used in the composition of the material is Fusha, both in terms of the material content and the examples are given.

\section{a. Gradation}

William Francis Mackey views two main aspects of gradation, namely: grouping and sorting. The Arabic textbook "Takallam Bil 'Arabiyyah Volume 6" in its presentation of the material has applied gradations. Grading techniques in ordering material in the Arabic textbook "Takallam Bil 'Arabiyyah Volume 6" can be seen in the arrangement of material from the beginning of the chapter to the end of the chapter which is arranged according to four aspects of language skills, namely: Listening, Speaking, Reading, and Writing. Each chapter in the material is equipped with examples of simple conversations according to the topic of discussion.

Table 2. Simple conversations
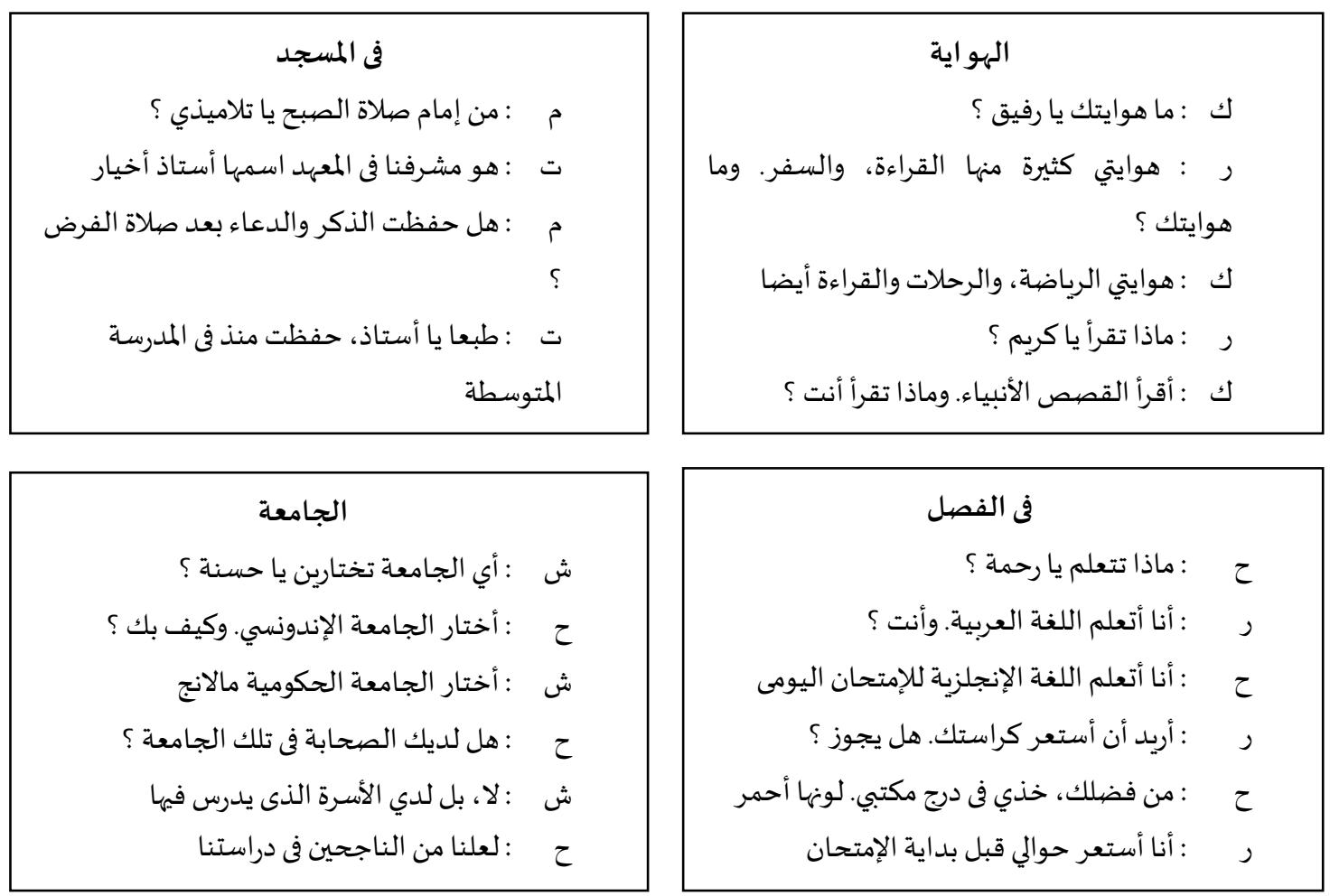

Apart from the main aspects above, at the end of each chapter, a mufradat aspect is added which is taken from the vocabulary contained in the themes that have been studied. Researchers assess that this additional mufradat

helps students to understand the material being taught so that teachers do not need 
to explain the meaning of every vocabulary in the teaching material. The second, the grading technique (sorting). In the textbook "Takallam Bil 'Arabiyyah Volume 6" the author has compiled material based on gradation techniques. This can be seen from the selection and placement of topics from easy, simple word choices, simple examples to difficult topics. Each chapter is equipped with pictorial material that makes it easier for students to understand the topic of discussion. Each chapter contains simple grammatical aspects, such as mubtada, khobar, fa'il, fi'il sentence forms, naibul fa'il, 'amil jawazim and nawaasib.

\section{a. Presentation}

Presentation of the material in the book "Takallam Bil 'Arabiyyah Volume 6" is viewed from several system models put forward by William Francis Mackey in his presentation: 1) Differentiation procedure (explanation in the first language) When viewed from a differential procedure point of view, the material "Takallam Bil' Arabiyyah Volume 6 "uses Indonesian as the preface, as well as in the learning process even though the material is in Arabic. The teacher does not need to explain the vocabulary of the teaching material into the language of the students, because simple word selection makes it easier for students to understand the vocabulary. For example, الساعة، العمل، المهنة، السفر، البيانات الشخصية ostensive procedure (using an object or action). In terms of ostensive procedures, the textbook encourages teachers to use body language as a means of making it easier for students to understand teaching material. Like when teaching about العمل (work), when students hear the word العمل that comes to their mind is that all work activities that are done are called العمل. Whereas what is meant by the word is heavy work done outside the home, such as gardening, teaching, etc. 3) Pictorial procedure (using pictures). Based on the researcher's analysis of the textbook "Takallam Bil 'Arabiyyah Volume 6", the teacher is deemed not necessary to use tools or objects in explaining the material. Because the selection of Arabic vocabulary in the teaching materials is taken from the things closest to the students. However, how much more a good understanding is to students, researchers recommend teachers to use media such as LCDs or images related to the material being studied.

\section{b. Repetition}

The textbook "Takallam Bil 'Arabiyyah Volume 6" was prepared as a means to assist students in developing language skills. Not only strengthening teaching materials, strengthening the practical aspects, and applying the material that has been taught into real action. The book "Takallam Bil 'Arabiyyah Volume 6" is equipped with four language skills that students must have, namely: listening skills, good Arabic speaking skills, reading skills in Arabic text in accordance with grammatical aspects, and writing skills in correct Arabic letters based on the provisions of writing letters. Arabic according to Imla 'Al-'Araby.

\section{CONCLUSIONS}

Based on the in-depth analysis that has been carried out by researchers on the textbook "Takallam Bil 'Arabiyyah Volume 6", it can be concluded that the textbooks compiled by Mamluatul Hasanah contain Mackey's concepts in several aspects, but in other aspects, the preparation of materials is arranged based on school needs. Mackey's concept in the textbook "Takallam Bil 'Arabiyyah Volume 6" can be seen in selecting material, the author chooses material that is closer to students, namely الساعة ، العمل ، المهنة، السفر ، البيانات 
الشخصية ، العمل في المجتمع in the concept of gradation, The author ranks the material from things that students always see, such as "as-sa'ah" to social activities "al-'Amal fi al-Mujtama '. In the concept of presentation, the writer presents the material using standard vocabulary (fusha), at the end of each chapter, the writer loads the difficult vocabulary contained in the material. At the repetition stage, the author completes the textbook "Takallam Bil 'Arabiyyah Volume 6" with four language skills, namely istima', kalam, qira'ah and kitabah. However, the students 'speaking skills are paid more attention in the presentation of the material according to the name of the book "Takallam Bil' Arabiyyah".

\section{ACKNOWLEDGMENT}

Researchers are grateful to be able to complete an analytical study of the Arabic textbook "Takallam Bil 'Arabiyyah Volume 6". Therefore, the researchers would like to thank SMA Islam Sabilillah Malang Boarding School for allowing researchers to analyze the Arabic textbooks used. I hope this study will be of benefit to the SMA Islam Sabilillah Malang Boarding School and schools wishing to compile Arabic textbooks.

\section{BIBILIOGRAPHY}

Ahmad, Z. A. (2015). Pengembangan Model Pembelajaran Bahasa Arab Berbasis Teori Multiple Intelligence. Al Mahära: Jurnal Pendidikan Bahasa Arab, 1(1), 1-18. https://doi.org/10.14421/almahara.2015.011-01

Akbar, M. I., \& Yusuf, M. (2018). Desain Penulisan Buku Ajar Bahasa Arab (Analisis Deskriptif Buku Al-'Arābiyyah Baina Yadaik). Edulab: Majalah Ilmiah Laboratorium Pendidikan, 3(2), 50-72. http://ejournal.uinsuka.ac.id/tarbiyah/index.php/edulab/article/view/3368

Febriani, S. R. (2020). Analisis Implementasi Pembelajaran Bahasa Arab di Sekolah Dasar: HOTS, MOTS, LOTS ? Prosiding Konferensi Nasional Babasa Arab VI (KONASBARA), 20, 432-444. index.php/konasbara/article/view/695

Fitriani, N., \& Saefuloh, H. (2018). Analisis Bahan Ajar Buku Siswa Bahasa Arab Untuk Kelas 6 Madrasah Ibtidaiyah (Pendekatan Saintifik 2013). EL-IBTIKAR: Jurnal Pendidikan Bahasa Arab, 7(2), 115-136. https://doi.org/10.24235/ibtikar.v7i2.3336

Hadi, N. (2018). Analisis Content Buku Ajar Bahasa Arab (Pendekatan Saintifik Kurikulum 2013) Kelas I Madrasah Ibtidaiyah Terbitan Kementerian Agama Republik Indonesia 2014. Ijaz. Arabi Journal of Arabic Learning, 1(1), 37-51. https://doi.org/10.18860/ijazarabi.v1i1.4930

Imam Makruf, A. B. (2020). Peningkatan Mutu Pembelajaran Bahasa Arab Berbasis Aktivitas Di Madrasah Ibtidaiyah. Al-Mahara Jumal Pendidikan Bahasa Arab, 6(1 Juni), 39-58. https://doi.org/DOI: 10.14421/almahara.2020.061-03

Irfan, H. (2020). Analisis Faktor-Faktor Kesulitan Menulis Huruf Abjad Bahasa Arab (Studi Kasus Pada Siswa Kelas VIII SMP Miftahul Iman Bandung). Lisanan Arabiya: Jurnal Pendidikan Babasa Arab, 3(2), 129-152. https://doi.org/https://doi.org/10.32699/liar.v3i2.1054

Ninoersy, T., ZA, T., \& Wathan, N. (2019). Manajemen Perencanaan Pembelajaran Bahasa Arab Berbasis Kurikulum 2013 Pada SMAN 1 Aceh Barat. Fitrab: Jurnal Kajian IlmuIlmu Keislaman, 05(1), 83-102. http://dx.doi.org/10.24952/fitrah.v5i1.1759

Pahlefi, M. R. (2020). Analisis Buku Al-'Arabiyyah Baina Yadaik Jilid I. Al-Ittijah:Jurnal 
Keilmuan Dan Kependidikan Bahasa Arab, 12(2), 157-176. https://doi.org/http://dx.doi.org/10.32678/al-ittijah.v12i2.3630

Ramah, S., \& Rohman, M. (2018). Analisis Buku Ajar Bahasa Arab Madrasah Aliyah Kurikulum 2013. Arabiyatuna: Jurnal Babasa Arab, 2(2), 141-160. https://doi.org/10.29240/jba.v2i2.552

Setyawan, C. E., \& Ahsan. (2020). Arah Perencanaan Pembelajaran Bahasa Arab Abad 21. Jurnal Komunikasi Dan Pendidikan Islam, 9(1), 55-82. https://doi.org/https://doi.org/10.36668/jal.v9i1.133

Setyawan, C. E., Basit, L. A., \& Fathoni, M. (2018). Telaah Bahan Ajar Bahasa Arab "Ayo Fasih Berbahasa Arab" Madrasah Aliyah Kelas XII Karya Hasan Saefullah (Tinjauan Materi Berdasarkan Teori Mackey). Prosiding Konferensi Nasional Bahasa Arab IV, 1-10. http://prosiding.arab-um.com/index.php/konasbara/article/view/273

Sumardi, M. (1974). Pengajaran Bahasa Asing: Sebuah Tinjauan Dari Segi Metodologi. Bulan Bintang.

Tarigan, H. G., \& Tarigan, D. (1986). Telaah Buku Teks Bahasa Indonesia (Cet. II). Angkasa. 
